\title{
他部位骨髄炎に続発した化膿性春椎炎について
}

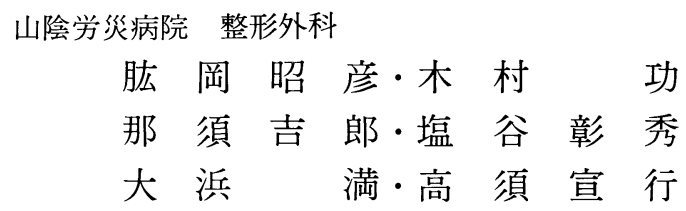

\section{Pyogenic Osteomyelitis of the Spine Followed Another Part's Osteomyelitis}

by

A. Hijioka, H. Singu, I. Kimura, Y. Nasu, A. Siotani, M. Oohama, N. Takasu

Department of Orthopaedic Surgery

San-in Rosai Hospital, Yonago, Japan.

Recently pyogenic osteomyelitis of the spine have been more and more often reported.

But the sources of prime origin are unknown in most cases. 28 cases were treated by operative methods in the last 15 years in our hospital. Only 2 cases of these followed another part's osteomyelitis.

We disscussed these two cases. One case, which is induced by osteomyolitis of humeral shaft, is rare. We must do long follow up to osteomyelitis and care of neurological sign from these patients.

\section{はじめに}

近年，化膿性脊椎炎が增加しつつあることが報告さ れているが，その発症機序や感染径路については，不 明なものが多い。

過去15年間に当院で手術的に加療した化膿性脊椎炎 は，28例で，その内訳は頸椎 5 例（18\%）胸椎 4 例 (14\%) 腰椎19例 $(68 \%)$ であるが，これらの中で明 らかに他部位骨髄炎に続発した化膿性合椎炎は，2 例 のみであった．今回，これらの 2 例について検討を行 つたので報告する。

症例 1

69才，男性，職業漁士

主訴：両下肢機能障害，右足関節痛

現病歴：昭和54年より慢性関節リウマチの診断にて, 関節内注射などの治療を受けていたが，昭和55年12月 に左膝関節痛が増強し，左膝化膿性膝関節炎及び脛骨 骨髄炎にて左膝関節固定術を施行．昭和56年 4 月右足
関節痛が出現し，右化膿性足関節炎の診断で右足関節 固定術を受けている。

今回，昭和 58 年 6 月より腰痛が出現，その後急速な 両下肢の運動知覚障害にて歩行困難となる．昭和58年 7 月右足関節外果部の発赤腫脹が出現，自然排膿した ため当院紹介入院となる.

既往歴，家族歴：特記所見なし。

現症：右足関節に腫脹，発赤，熱感があり瘦孔部よ り排膿を認めた。

脊椎には，可動域制限，傍脊柱筋の圧痛及び第10胸 椎の掌圧痛が見られた.

神経学的所見: 腱反射は右膝蓋腱反射, 左アキレス 腱反射とも正常，知賞は下腹部以下の知賞障害があり， 筋力は左下肢に著明な低下を認めた。（表 1)

臨床検査成績：血液一般で, 白血球9100とやや増加, CRP $3+$, 血沈126/hour と六進していた.

血液生化学：特に異常所見なし.

髄液検査：細胞数と蛋白の著明な増加がみられた。 


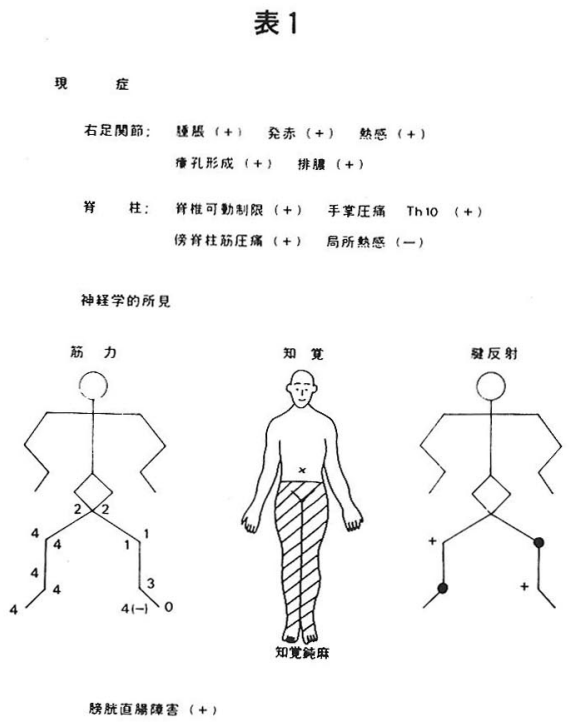

表 2

臨床㭘査成績（昭和58年 7 月 18 日）

\begin{tabular}{llll} 
血液一般 & \multicolumn{3}{c}{ 生化学検査 } \\
WBC & 9100 & GOT & $13 \mathrm{U}$ \\
$\mathrm{RBC}$ & $448 \times 10^{4}$ & $\mathrm{GPT}$ & $7 \mathrm{U}$ \\
$\mathrm{Hb}$ & $12.6 \mathrm{~g} / \mathrm{dl}$ & $\mathrm{TP}$ & $8.8 \mathrm{~g} / \mathrm{dl}$ \\
$\mathrm{Ht}$ & $36.8 \%$ & $\mathrm{~A} / \mathrm{G}$ & 0.7 \\
& & $\mathrm{BUN}$ & $23.5 \mathrm{mg} / \mathrm{dl}$ \\
$\mathrm{CRP}$ & $(\mathrm{m})$ & $\mathrm{CRNN}$ & $0.8 \mathrm{mg} / \mathrm{dl}$ \\
$\mathrm{ESR}$ & $126 /$ hour & GLU & $60 \mathrm{mg} / \mathrm{dl}$
\end{tabular}

蹃液検查

細胞数 $13 / 3$ 蛋白 $400 \mathrm{mg} / \mathrm{dl}$ 糖 $34 \mathrm{mg} / \mathrm{dl}$

\section{(表 2)}

レ線所見：入院時の胸椎断層撮影にて第 9 胸椎椎体 下縁第10胸椎椎体，第11胸椎椎体上縁に骨破壊像を認 め椎間は狭小化している.（図 1)

${ }^{99 \mathrm{~m}} \mathrm{~T} \mathrm{c}$ 骨シンチ：第10, 11 胸椎と右足関節に集積像 を認めた。（図 2 )

蓨髄造影：第 9 胸椎下縁より第11胸椎中央部までの ブロックがみられた。(図3)

細菌培養 : 右足関節の排膿部の細菌培養にて黄色ブ ドウ球菌が検出された.

以上の検査結果より，右足関節に続発した化膿性背 椎炎，結核性背椎炎等を考慮して，昭和58年 8 月 2 日 に手術を施行した。

手術は, 開胸にて前方より侵大し第10,11胸椎に達

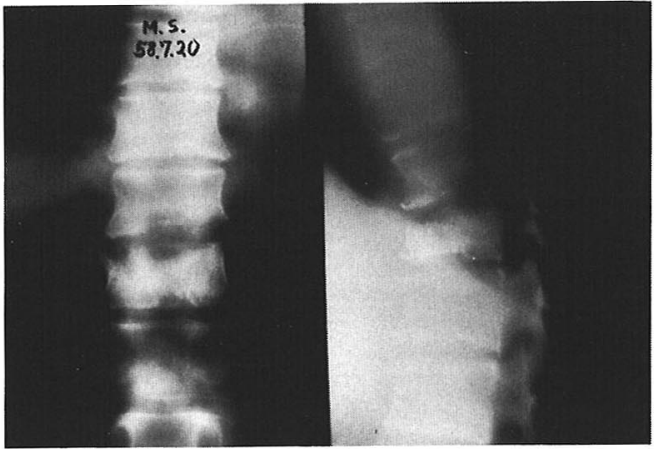

図 1 第10胸椎椎体の破壊像. 断層写真

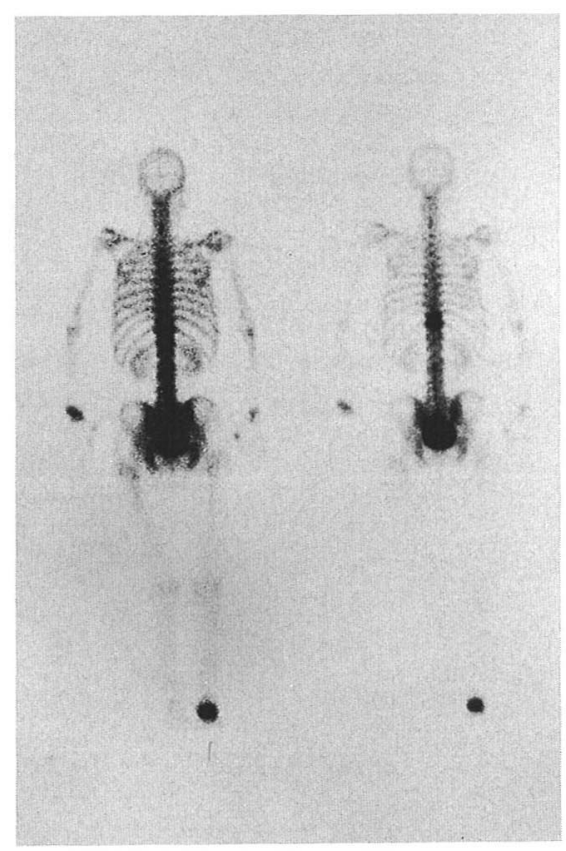

図 2 第10,11胸椎および右足関節の集積像. 骨シンチ

すると椎間は，肉芽組織と壊死組織で置換されており これらを搔爬して，腸骨の骨移殖を行った。（図 4) 術中組織培養にて黄色ブドウ球菌が検出された. 術後, セファロスポリン系抗生剤の点滴とアミノグ ルコシッド系抗生剤の筋注を約 1 力月施行, 症状は軽 快し, 一本杖歩行にて退院した。

症例 2

59 才, 男性, 職業農業

主訴：両上下肢機能障害，右上腕痛 
表 3

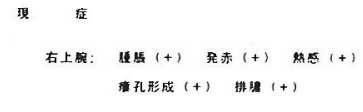

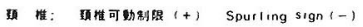

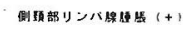

称择学的所見
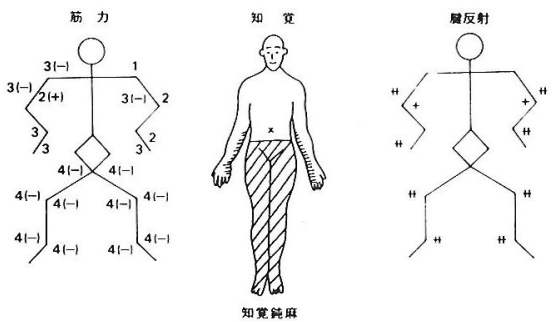

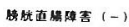

表 4

臨床検查成績（昭和62年 5 月 7 日）

\begin{tabular}{llll} 
血液一般 & \multicolumn{3}{c}{ 生化学検査 } \\
WBC & 12100 & GOT & $11 \mathrm{U}$ \\
$\mathrm{RBC}$ & $296 \times 10^{4}$ & $\mathrm{GPT}$ & $9 \mathrm{U}$ \\
$\mathrm{Hb}$ & $8.8 \mathrm{~g} / \mathrm{dl}$ & $\mathrm{TP}$ & $6.9 \mathrm{~g} / \mathrm{dl}$ \\
$\mathrm{Ht}$ & $27 \%$ & $\mathrm{~A} / \mathrm{G}$ & 0.8 \\
& & $\mathrm{BUN}$ & $14.7 \mathrm{mg} / \mathrm{dl}$ \\
$\mathrm{CRP}$ & 0.99 & $\mathrm{CRNN}$ & $1.0 \mathrm{mg} / \mathrm{dl}$ \\
$\mathrm{ERS}$ & $130 /$ hour & GLU & $96 \mathrm{mg} / \mathrm{dl}$
\end{tabular}

髄液検查

細胞数 $1 / 3$ 蛋白 $15 \mathrm{mg} / \mathrm{dl}$ 糖 $45 \mathrm{mg} / \mathrm{dl}$

$45 \mathrm{mg} / \mathrm{dl}$

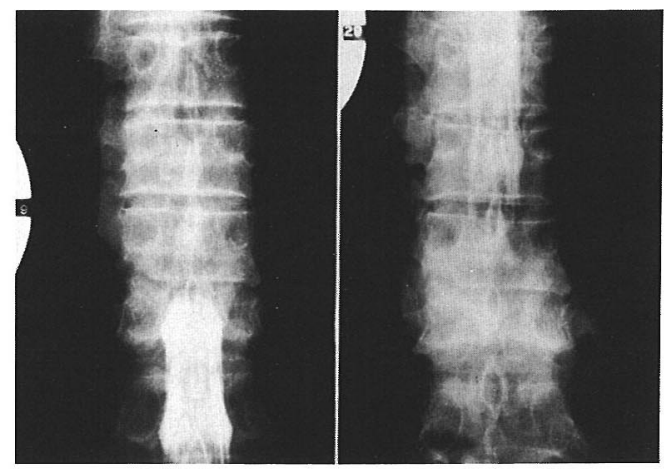

図 3 第 9 胸椎下縁より第 11 胸椎中央部までの ブロック像. ミエログラム

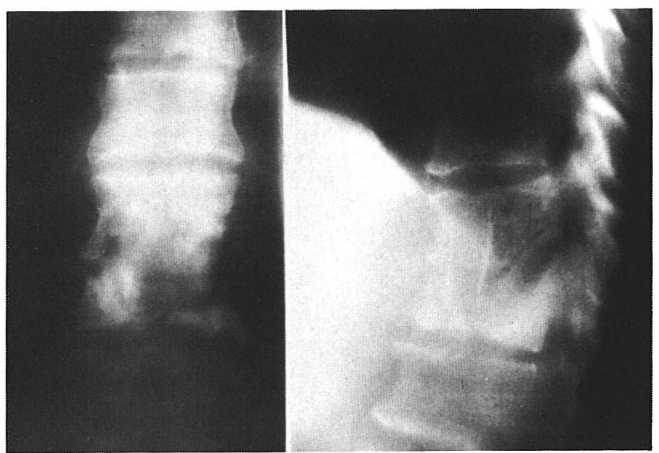

図 4 第10,11胸椎椎体部への植骨. 術後断層写真

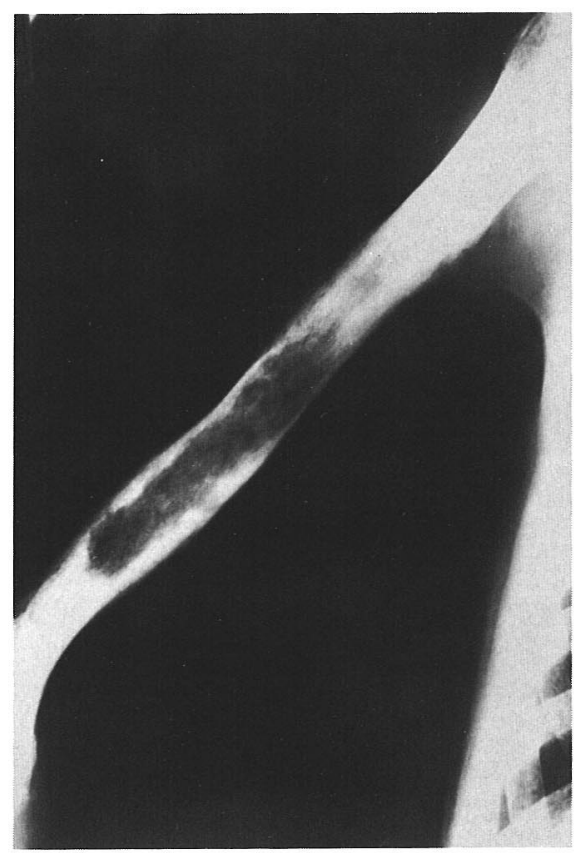

図 5 右上腕骨の骨透亮像の元進と骨皮質不整 像. 初診時 X線写真

現病歴：30年前に，右上腕骨骨髄炎にて切開排膿を 受けているが, 原因は不明であった. 昭和 62 年 4 月初 旬より右上腕痛が出現し, 近医にて右上腕骨化膿性骨 髄炎再発の診断で入院加療を行うが, 項部痛及び両上 下肢機能障害が出現したため昭和 62 年 5 月 6 日当院紹 介人院となる。

既往歴：アルコール性肝障害と糖尿病があり糖尿病 はインシュリンにて加療中であった。

家族歴：特記所見なし. 


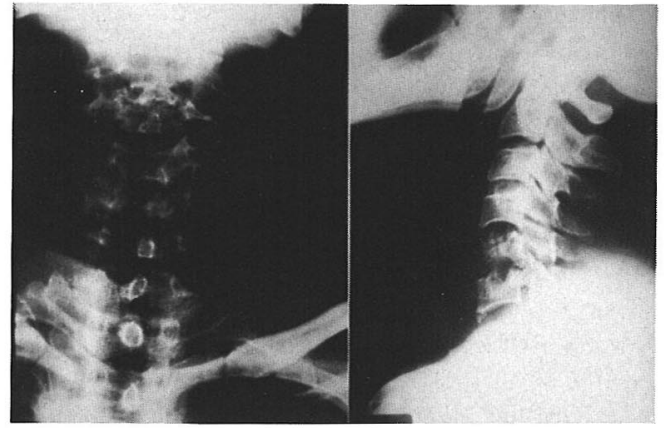

図 6 第 5 頚椎椎体および給 6 頝椎椎体上縁の 破壊像. 頚椎X 線写真

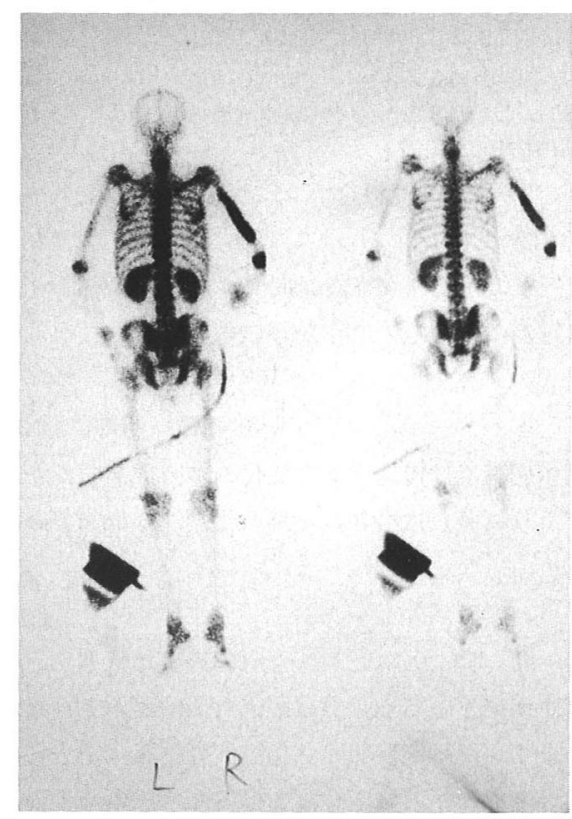

図 7 右上腕および第 5 頝椎への著明な取り込 み。骨シンチ
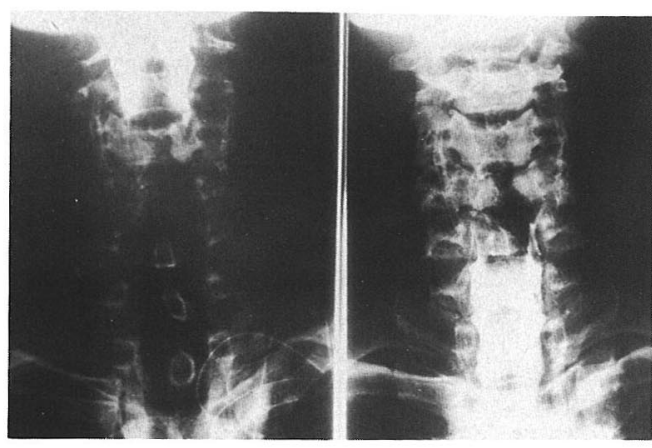

図 8 第 3 頝椎より第 7 頝椎までのブロック像. ミエログラム

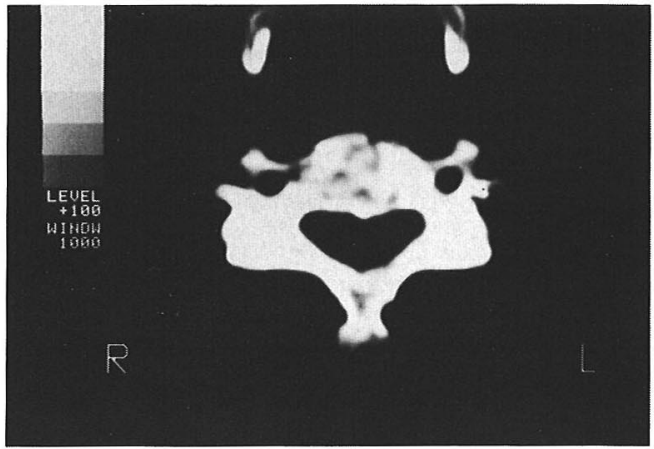

図 9 第 5 頝椎椎体の砂壊像. MCT

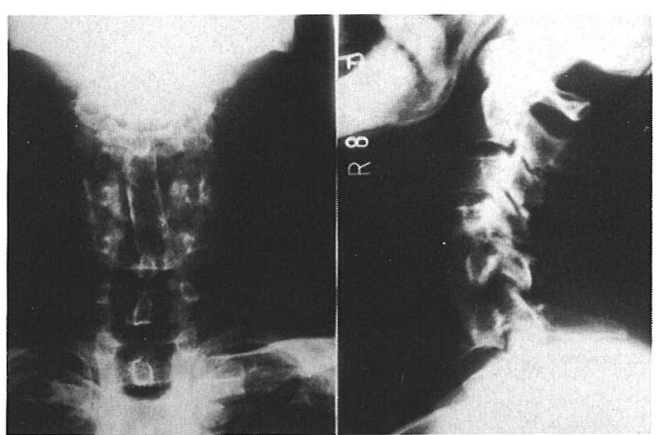

図10 第 5,6 頚椎椎体への植骨術後. 術後X線写真

現症：右上腕に発赤，腫脹，熱感を認め瘦孔部より 排膿あり。

頸椎では可動域制限と側頸部リンパ腺の腫脹がみら れた.

神経学的所見：橈骨反射以下の腱反射の充進，両前 腕尺側と下腹部以下の知覚障害及び両上肢の筋力低下 がみられたが, 膀胱直腸障害は認めなかった。（表 3 )

臨床検査成績: 血液一般で白血球が12100, CRP 0.99, 血沈130/hour と元進していた.

血液生化学：特に異常值を認めず，空腹時血糖も正 常値であった。（表 4)

単純レ線所見：右上腕骨の骨透亮像の元進と骨皮質 の不整像がみられ（図 5 ), 頸椎では第 5 頸椎椎体と第 6 頸椎椎体上縁の骨破壊像を認めた。（図6）

${ }^{99 \mathrm{~m}} \mathrm{Tc}$ 骨シンチ：右上腕骨と第 5 頸椎への著明な集 積がみられた。(図 7)

春髄造影：第 3 頸椎椎体下縁より第 7 頸椎椎体上縁 までのブロックがみられた.（図 8 ) 
MCT：第 5 頸椎椎体の破壊が明瞭であった.(図 9)

これらの所見から, 右上腕骨骨髄炎より続発した化 膿性春椎炎を考慮して昭和 62 年 5 月 12 日に手術を施行 した.

手術は，右上腕骨に対し病巣搔爬と持続洗浄術を行 い, 頸椎は前方より侵入し第 4,5 頸椎椎間部の壊死 組織及び肉芽組織を搔爬して第 5 頸椎椎体と第 6 頸椎 椎体上 1 / 3 を切除, 腸骨を植骨して手術を終えた.

術後約 3 週間セファロスポリン系抗生剤の点滴とア ミノグルコシッド系抗生剤の筋注にて症状は軽快, 術 後 3 ケ月で上肢の筋力は $\mathrm{G}$ レベルまで回復し退院した.

\section{考察}

化膿性春椎炎の誘因としての先行感染として, 尿路 系感染症, 呼吸器系感染症, 化膿性関節炎などが多い ことが報告されているが，長管骨骨髄炎に続発した症 例の報告は稀である. 今回, 先行感染としては稀な, 化膿性関節炎による関節固定術後の骨髄炎に続発した 化膿性䁈椎炎と上腕骨骨髄炎に続発した化膿性资椎炎 について報告した。

これら 2 症例の感染径路について考察すると, 血行 性転移が最も疑われるが，その根拠は明瞭ではない. 症例 1 の足関節から胸椎への転移は, 奇静脈の側副血 行路によるものが推測される.

次に, 骨髄炎患者の経過観察を行うと, 症例 2 のご とく一度治癒したと考えられた骨髄炎が多年を経てか ら再発する症例が多数みられる．特に何か他の疾患に より感染防御機構の低下がみられた時に起こって来る 事が多い.この様な症例をみると骨髄炎に完治はあり うるのだろうかと考えさせられる.これらの事実から 再発の原因を推論すると先ず病巣部の細菌が完全には 死滅しておらず体内で共存して棲息しているのか，あ るいは一度骨髄炎の起こった部位には，再発しやすい 環境があるのか等が考えられるが，これらも推論の域 を出ない.
我々の経験した 2 症例の反省点として, 当然のこと ながら骨髄炎患者に対しては定期的な経過観察が必要 であり,これらの症例に神経学的所見の出現した時に は，化膿性骨椎炎を考虑して診察にあたるのが肝要と 考えられた。

\section{文献}

1）宮本達也, 他：最近の化膿性春椎炎について, 臨整 外. $21: 531-539,1986$

2) Griffiths HED, et al: Pyogenic infection of the spine. J Bone Joint Surg 53-B : 313-391, 1971

3 ) Kemp HBS, et al: Pyogenic infections occsrring primarily in intervertibral Discs. J Bont Joint Surg 55-B : 698-714, 1973

4) Stauffer, R. N: Pyogenic vertebral osteomye litis. Orth Clinics of North America Vo 16 1015-1027, 1975

\section{質 問}

症例 1 の化膿性脊椎炎発症部位での，RA 性の変化 は如何がなったでしょうか。

\section{解 答 山陰労災病院 肱岡 昭彦} 術中病理では慢性炎症性変化の診断であったが，病 巣部よりブ菌が検出された為, 化膿性春椎炎と診断し た.
質 問
山口大学 斉鹿稔

麻痺が発生してから数日経過して，手術を行なわれ ていますが，臨床症状から化膿性脊椎炎は十分考えわ れ，早期の除圧と確定診断を得るため，緊急手術を行 なうべきであった症例ではないでしょうか.

\section{解 答山陰労災病院 肱岡 昭彦}

全麻に対する検査およびミエロ，CT 等の検査で入 院より手術まで数日経過しているが，出来るだけ早期 の手術適応と考えます. 